\title{
Pengaruh Manajemen Peternak Terhadap Efesiensi Reproduksi Sapi Bali Di Kabupaten Pringsewu Provinsi Lampung
}

\section{The Influence of Farmer Management on Bali Cattle Reproduction Effeciency In Pringsewu Regency, Lampung Province}

\author{
Sri Suharyati ${ }^{1}$ dan Madi Hartono ${ }^{1}$ \\ ${ }^{1}$ Jurusan Peternakan, Fakultas Pertanian, Universitas Lampung \\ Jln. Prof. Soemantri Brodjonegoro, No. 1, Bandar Lampung 35145 \\ E-mail : madihartono66@yahoo.co.id
}

\begin{abstract}
The aim of this research was to determine the effect of farmer management on Bali cattle reproduction efficiency in Pringsewu Regency, Lampung Province. This study was conducted in August_-September 2015 to 108 farmers and 143 Bali with census method. Data were analyzed by logistic regression and multiple regression.

The results showed that the CR was $51,75 \%$ with kind of grass that negatively associated with factor value 0,199, wall of cow's pen that positively associated with factor value 1,455, and sanitation of cow's pen that positively associated with factor value 0,510, body conditioning score that negatively associated with factor value 0,533 and first mating age that negatively associated with factor value 0,059. The CI was 416,69 $\pm 70,03$ days with farmer's reason that negatively associated with factor value 28,379, floor of cow's pen that positively associated with factor value 19,880, age of weaning calf that positively associated with factor value 0,076, first mating age that positively associated with factor value 0,972, and state of reproduction that negatively associated with factor value 125,306. The S/C was 1,76 with farmer education that negatively associated with factor value 0,200, large of cow's pen that negatively associated with factor value 0,016, and sanitation of cow's pen that negatively associated with factor value 0,297. The RB was 18,18\% with farmer's duration that negatively associated with factor value 0,059, the amount of water that negatively associated with factor value 0,058, large of cow's pen that negatively associated with factor value 0,109 and sanitation of cow's pen that negatively associated with factor value 1,154.
\end{abstract}

Key words : Bali cattle, farmer management, CR, CI, SC, RB

Diterima: 22 Oktober 2015, disetujui 27 Desember 2015

\section{PENDAHULUAN}

Sapi Bali memiliki banyak keunggulan yaitu cepat berkembang biak, tingkat kesuburannya/fertiltasnya tinggi, mudah beradaptasi dengan lingkungannya, dapat hidup di lahan kritis, mempunyai daya cerna yang baik terhadap pakan dan persentase karkas yang tinggi. Kemampuan lain yang dapat diandalkan untuk pengembangan populasi Sapi Bali adalah interval kelahiran yang cukup baik. 
Upaya yang dilakukan untuk meningkatkan populasi dan genetik Sapi Bali melalui teknologi Inseminasi Buatan (IB) yang diterapkan pada peternakan rakyat. Dengan IB peternak tidak perlu memelihara sapi pejantan sehingga kemungkinan terjadinya inbreeding dapat dihindari. Namun, IB dapat merugikan peternak akibat peternak dalam melakukan deteksi birahi kurang akurat dan inseminator kurang trampil.

Salah satu permasalahan yang sering dijumpai oleh petani ternak dalam mengembangkan populasi ternak adalah rendahnya efisiensi reproduksi. Untuk mengetahui tinggi rendahnya efisiensi reproduksi dapat dilakukan dengan menghitung angka kebuntingan atau conception rate; jarak antara melahirkan atau calving interval; angka perkawinan per kebuntingan atau service per conception; dan angka kelahiran atau calving rate; serta repeat breeder (Hardjopranjoto, 1995). Dengan mengetahui nilai efisiensi reproduksi dan faktor-faktor manajemen peternak yang memengaruhinya diharapkan mampu untuk memecahkan permasalahan yang menyebabkan rendahnya efisiensi reproduksi, dengan demikian akan membantu program percepatan peningkatan populasi ternak khususnya ternak sapi.

\section{METODE}

Penelitian dilaksanakan Agustus-September 2015 di Kabupaten Pringsewu meliputi 108 peternak dan 143 sapi Bali yang diiseminasi buatan. Metode penelitian yang digunakan adalah metode sensus. Data diperoleh dengan melakukan wawancara pada peternak, mengamati ternak dan manajemen pemeliharaan Sapi Bali secara langsung di lapangan, serta data akseptor yang diperoleh dari recording inseminator.

Analisis data yang digunakan dalam penelitian ini adalah analisis regresi berganda dan logistik regresi. Sebelum dilakukan analisis data, dilakukan pengkodean terhadap data inseminator kemudian diolah dalam program SPSS (statistik packet for social science) (Sarwono, 2006). Variabel untuk peternak adalah alasan beternak (X1), pernah mengikuti kursus di bidang peternakan (X2), pendidikan peternak (X3), lama beternak (X4), umur sapi (X5), skor kondisi tubuh (X6), umur pertama kali dikawinkan (X7), birahi pertama setelah kelahiran (X8), perkawinan postpartum (X9), gangguan reproduksi (X10), pemeriksaan kebuntingan (X11), status reproduksi (X12), frekuensi pemberian hijauan (X13), jumlah pemberian hijauan (X14), jumlah konsentrat (X15) sistem pemberian air minum (X16), jumlah pemberian air minum (X17), letak kandang dari rumah (X18), bentuk dinding kandang (X19), bahan lantai kandang (X20), bahan atap (X21), luas kandang (X22), sanitasi kandang (X23).

\section{HASIL DAN PEMBAHASAN}

Hasil survey di Kabupaten Pringsewu didapatkan108 orang dengan 143 ekor sapi yang di IB. Sebanyak 108 peternak Sapi Bali di Kabupaten Pringsewu belum pernah mengikuti kursus mengenai pemeliharaan Sapi Bali, selama ini pengetahuan beternak yang dimiliki berasal dari informasi turuntemurun serta hasil diskusi dengan inseminator dan sesama peternak. Alasan peternak memelihara Sapi Bali sebagai tabungan sebesar 96,30 \% dan pekerjaan utama sebesar 3,70\%, dengan lama beternak 8,8 7,32 tahun. Pendidikan formal peternak yaitu SD sebesar 65,74\%, SMP sebanyak $21,30 \%$, dan SMA sebesar 12,96\%. 
Jenis hijauan yang diberikan oleh peternak berupa rumput ilalang sebanyak $57,40 \%$, rumput gajah sebanyak $18,52 \%$, rumput wedusan sebanyak $14,81 \%$, jerami sebanyak $4,63 \%$, setaria sebanyak $3,70 \%$ dan hay jerami sebanyak $0,94 \%$. Frekuensi pemberian hijauan yang dilakukan oleh peternak sebanyak 1 kali/hari sebesar 39,81\%, 2 kali/ hari sebesar 39,81\%, tiga kali per hari sebesar 15,74\%, 4 kali/hari sebesar 3,70\%, dan 7 kali/hari sebesar 0,94\%. Rata-rata jumlah hijauan yang diberikan ke ternak sebanyak 53,01 $\pm 16,97 \mathrm{~kg} / \mathrm{ekor} / \mathrm{hari}$, sedangkan rata-rata pemberian air adalah $21,19 \pm 9,04$ liter/hari/ekor. Letak kandang sapi dari rumah peternak rata-ratanya adalah 7,26 $\pm 16,78$ meter. Bentuk dinding kandang yang terbuka sebanyak 90,74\%, sedangkan yang tertutup sebanyak 9,26\%, dengan luas kandang adalah $20,21 \pm 13,08 \mathrm{~m}^{2}$. Bahan lantai kandang berupa tanah sebanyak $89,81 \%$ dan berupa semen sebanyak 10,19\%. Peternak tidak membersihkan kandang sebanyak 14,82\%, 74,07\% membersihkan kandang 1 kali/hari, 7,41\% membersihkan kandang 2 kali/hari, dan 3,70\% membersihkan kandang 3 kali/hari.

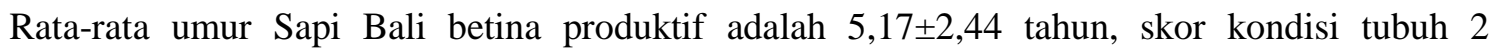
sebanyak 5,59\%; skor 3 sebanyak 70,62\%; skor 4 sebanyak 22,38\%; dan skor 5 sebanyak 1,40\%. Ratarata umur pertama kali dikawinkan adalah $20,54 \pm 4,41$ bulan, sedangkan rata-rata birahi pertama setelah kelahiran adalah $68,15 \pm 52,16$ hari. Rata-rata perkawinan postpartum adalah 78,33 $\pm 54,52$ hari. Gangguan reproduksi yang terjadi pada sapi sebesar 2,29\%, sedangkan sapi yang normal sebanyak 97,71\%. Status reproduksi Sapi Bali betina adalah induk sebanyak $83,92 \%$ dan dara sebanyak $16,08 \%$. Seluruh Sapi Bali yang di inseminasi buatan dilakukan pemeriksaan kebuntingan, lebih kurang tiga bulan setelah dilakukan inseminasi buatan.

Hasil penelitian menunjukkan bahwa efesiensi reproduksi sapi Bali di Kabupaten Pringsewu sebagai berikut conception rate (CR) sebesar $51,75 \%$, service per conception $(\mathrm{S} / \mathrm{C})$ sebesar 1,76, calving interval $(\mathrm{CI})$ sebesar 416,69 $\pm 70,03$ hari dan repeat breeder $(\mathrm{RB})$ sebesar $18,18 \%$.

\section{Faktor Manajemen Peternak terhadap CR}

Hasil analisis regresi berganda menunjukkan faktor manajemen peternak yang memengaruhi CR adalah jenis hijauan yang diberikan ke ternak dengan besar faktor 0,199 yang berasosiasi negatif, bentuk kandang dengan besar faktor 1,455 yang berasosiasi positif, dan sanitasi kandang dengan besar faktor 0,510 yang berasosiasi positif, skor kondisi tubuh dengan besar faktor 0,533 yang berasosiasi negatif dan umur pertama kali dikawinkan dengan besar faktor 0,059 yang berasosiasi negatif.

Salah satu faktor yang memengaruhi angka CR adalah kesuburan ternak. Ternak yang mendapatkan pakan yang kandungan nutrisinya baik maka proses pembentukan hormon-hormon reproduksi juga menjadi baik. Jenis hijauan seperti legum dan kacang-kacangan mengandung kadar protein yang lebih tinggi dibandingkan rumput lapang. Menurut Bearden dan Fuquay (1984), kekurangan nutrisi dalam jangka waktu yang lama akan menyebabkan ovarium tidak aktif sehingga siklus estrus tidak teratur bahkan menyebabkan anestrus. Semakin banyak peternak memberikan ternak yang kualitasnya jelek maka nila CR akan menurun.

Bentuk kandang memengaruhi nilai CR, kandang sapi yang baik adalah kandang yang sesuai dan memenuhi persyaratan kebutuhan dan keselamatan sapi. Apabila kedua hal tersebut tidak terpenuhi akan menyebabkan gangguan fungsi fisiologis termasuk gangguan reproduksi. Bentuk kandang terbuka dan luas yang memungkinkan untuk sirkulasi udara yang bagus sangat dibutuhkan untuk menunjang efisiensi reproduksi yang baik. Menurut Sudono (2003), persyaratan umum kandang sapi antara lain adalah sirkulasi udara dan sinar matahari yang cukup sehingga kandang tidak lembab. 
Kebersihan kandang memengaruhi nilai CR. Kandang yang bersih merupakan faktor penting untuk kesehatan ternak. Apabila kandang kotor akan menyebabkan banyak kuman penyakit yang akan menginfeksi ternak. Ternak yang sakit nafsu makan menjadi menurun, badan kurus, kondisi ini akan menyebabkan gangguan fungsi fisiologis tubuh termasuk gangguan proses reproduksinya. Hardjopranjoto (1995) menyatakan bahwa sanitasi lingkungan khususnya kandang sangat menentukan tingkat pencemaran organ reproduksi yang dapat berakibat timbulnya infeksi pada uterus dan menyebabkan kejadian kawin berulang.

Faktor skor kondisi tubuh memengaruhi CR, ternak dengan kondisi tubuh yang kegemukan cenderung banyak mengandung lemak dalam tubuhnya. Kandungan lemak yang tinggi dapat menutupi saluran reproduksi sehingga akan terjadi gangguan fungsi organ-organ reproduksi, namun demikian kondisi tubuh ternak yang sangat kurus juga akan menyebabkan menurunnya kemampuan tubuh untuk membentuk hormon-hormon reproduksi dan gangguan ovulasi. Menurut Bearden dan Fuquay (1984), apabila terjadi penimbunan lemak pada saluran reproduksi akibat kegemukan maka akan menyebabkan gangguan siklus estrus, angka kebuntingan rendah, distokia, abortus dan retensi pasenta.

Faktor umur pertama kali dikawinkan memengaruhi CR. Ternak yang baru pubertas dan belum dewasa kelamin apabila dikawinkan akan menyebabkan tingkat fertilitas rendah, hal tersebut disebabkan karena ternak yang belum dewasa kelamin nutrisi yang masuk di dalam tubuh akan digunakan untuk fungsi pokok terlebuh dahulu yaitu untuk pertumbuhan tubuh. Toelihere (1993) menganjurkan bahwa perkawinan dilakukan setelah dewasa kelamin, hal tersebut disebabkan ternak yang baru pubertas masih banyak membutuhkan nutrisi untuk perumbuhan tubuh.

\section{Faktor manajemen peternak terhadap CI}

Faktor manajemen peternak yang memengaruhi CI adalah alasan beternak dengan besar faktor 28,379 yang berasosiasi negatif dan lantai kandang dengan besar faktor 19,880 yang berasosiasi positif, umur penyapihan pedet dengan besar faktor 0,076 yang berasosiasi positif, umur pertama kali dikawinkan dengan besar faktor 0,972 yang berasosiasi positif, dan status reproduksi dengan besar faktor 125,306 yang berasosiasi negatif.

Alasan beternak memengaruhi CI. Peternak yang beternak sebagai usaha sambilan akan kurang memperhatikan ternaknya dan hal tersebut dapat berakibat peternak tidak mengetahui ternaknya sedang birahi. Toelihere (1993) menyatakan bahwa perkawinan yang tidak tepat akibat deteksi estrus yang terlambat akan menyebabkan kegagalan fertilisasi sehingga jarak untuk beranak akan menjadi lebih panjang.

Lantai kandang yang bersih dan tidak licin merupakan hal penting yang harus diperhatikan. Lantai kandang yang terbuat dari semen lebih mudah dibersihkan dan cepat kering bila terkena air, sebaliknya lantai kandang dari tanah akan lebih cepat kotor dan licin sehingga membuat ternak tidak nyaman dan lebih banyak mengandung sumber penyakit. Lantai kandang dari tanah akan cepat kotor sehingga akan mudah tercemar bakteri yang dapat menginfeksi saluran reproduksi. Hardjopranjoto (1995) menyatakan bahwa sanitasi lingkunan khususnya kandang sangat menentukan tingkat pencemaran organ reproduksi yang dapat berakibat timbulnya infeksi pada uterus dan menyebabkan kejadian kawin berulang. Kejadian kawin yang berulang akan semakin memperpanjang jarak kelahiran pada periode berikutnya.

Umur penyapihan pedet berasosiasi positif terhadap CI, artinya semakin lama anaknya disapih maka CI menjadi lebih panjang. Induk yang sedang menyusui akan mensekresikan hormone prolaktin dalam kadar yang tinggi. Menurut Hafez (2004), kadar hormon prolaktin yang tinggi akan memberikan umpan balik negatif kepada hipotalamus dan hipofisis sehingga terjadi penurunan 
hormone-hormon gonadotrophin yang berfungsi untuk estrus dan ovulasi. Ketiadaan estrus dan ovulasi akan menyebabkan perkawinan yang infertil dan hal tersebut akan menyebabkan jarak melahirkan periode berikutnya akan menjadi lebih panjang.

Umur pertama kali dikawinkan berasosiasi positif, hal ini berarti semakin lama ternak dikawinkan maka jarak beranak menjadi makin panjang. Menurut Toelihere (1993), waktu yang ideal untuk dikawinkan pada sapi adalah umur 12-15 bulan.

\section{Faktor manajemen peternak terhadap $S / C$}

Faktor peternak yang memengaruhi S/C adalah pendidikan peternak dengan besar faktor 0,200 yang berasosiasi negatif, luas kandang dengan besar faktor 0,016 yang berasosiasi negatif, dan sanitasi kandang dengan besar faktor 0,297 yang berasosiasi negatif.

Hasil penelitian menunjukkan bahwa pendidikan peternak berasosiasi negatif terhadap SC, artinya semakin tinggi pendidikan peternak maka akan menurunkan S/C. Peternak yang memiliki pendidikan yang tinggi akan mudah menerima ilmu pengetahuan tentang beternak yang baik. Pengetahuan peternak tentang manajemen pemeliharaan dan manajemen reproduksi yang baik akan meningkatkan efisiensi reproduksi. Menurut Sudono (2003), peternak yang mempunyai pendidikan yang lebih tinggi akan mudah menerima informasi-informasi yang baru yang sangat berguna untuk meningkatkan efisiensi reproduksi.

Luas kandang memengaruhi S/C, semakin luas kandang akan menurunkan S/C. Kandang yang cukup luas akan memudahkan peternak untuk melakukan deteksi birahi sehingga bisa dilakukan perkawinan tepat waktu. Ginting dan Sitepu (1989) dalam Hartono (1999) menyatakan bahwa ratarata setiap ekor sapi membutuhkan luas lantai 3,5-4,0 $\mathrm{m} 2$ belum termasuk bahan untuk tempat pakan, tempat air minm, dan selokan tempat pembuangan air.

Sanitasi kandang berpengaruh terhadap S/C, semakin bersih kandang maka S/C menurun, sebaliknya kandang yang kotor akan memperbesar S/C. Apabila kandang kotor akan menyebabkan banyak kuman penyakit yang akan menginfeksi ternak . Ternak yang sakit nafsu makan menjadi menurun, badan kurus, kondisi ini akan menyebabkan gangguan fungsi fisiologis tubuh termasuk gangguan proses reproduksinya.

\section{Faktor manajemen peternak terhadap $R B$}

Faktor peternak yang memengaruhi RB adalah lama beternak dengan besar faktor 0,059 yang berasosiasi negatif, jumlah pemberian air dengan besar faktor 0,058 yang berasosiasi negatif, luas kandang dengan besar faktor 0,109 yang berasosiasi negatif dan sanitasi kandang dengan besar faktor 1,154 yang berasosiasi negatif, dan umur pertama kali dikawinkan dengan besar faktor 0,119 yang berasosiasi positif.

Lama beternak berpengaruh dan berasosiasi negatif terhadap kejadian $\mathrm{RB}$, hal ini berarti semakin lama beternak akan menurunkan RB. Peternak yang beternak sudah lama akan memiliki pengalaman memelihara ternaknya lebih baik, termasuk pengetahuan untuk deteksi estrus. Menurut Parkinson (1996) dalam Hartono (1999), deteksi estrus merupakan kunci keberhasilan suatu perkawinan. Pelaporan estrus yang tepat kepada inseminator memungkinkan pelaksanaan perkawinan pada waktu yang tepat.

Jumlah pemberian air berasosiasi negatif yang artinya pemberian air yang tidak dibatasi (ad libitum) akan menurunkan RB. Air merupakan komponen penting dan terbesar dalam tubuh hewan dalam bentuk darah. Menurut Irwan (2011), air sangat dibutuhkan dalam berbagai fungsi biologis dan metabolisme tubuh seperti pengaturan suhu tubuh, membantu proses pencernaan, pengangkut nutrisi, 


\section{Jurnal Pertanian Terapan}

pengaturan hormon, pertumbuhan fetus, produksi susu, dan mengeluarkan bahan-bahan yang sudah tidak berguna dari dalam tubuh sapi.

Menurut Raffly (2008) kebutuhan air pada masing-masing hewan sangat bervariasi tergantung oleh berbagai faktor seperti jenis dan ukuran tubuh hewan; status fisiologis hewan; tingkat aktifitas ternak; jenis dan kualitas pakan; kualitas air, rasa dan salinitas air; jarak dan ukuran tempat air minum; temperature air dan temperature udara. Menurut Saka (1990), kebutuhan air minum bagi sapi sebanyak 20 - 40 liter/ekor/hari. Hewan bunting, menyusui dan pada masa pertumbuhan membutuhkan lebih banyak air. Sapi yang menyusui membutuhkan tambahan $0,86 \mathrm{~kg}$ air $/ \mathrm{kg}$ susu. Sapi bunting dan pedet meningkatkan konsumsi air 30-50\%. Air dalam jumlah dan kualitas yang cukup, menjamin kelangsungan fungsi tubuh ternak secara normal termasuk fungsi reproduksi.

Kekurangan air merupakan salah satu penyebab penurunan efisiensi reproduksi karena selalu diikuti oleh adanya gangguan reproduksi pada hewan betina maupun jantan. Pemberian air yang tidak cukup dapat menyebabkan tidak aktifnya ovarium dan tidak munculnya estrus pada sapi betina dewasa. Rendahnya kadar hormon LH dalam darah dapat menyebabkan terjadinya delayed ovulasi (ovulasi tertunda) dan sista folikuler, karena rendahnya kadar LH, fase folikuker diperpanjang sehingga yang seharusnya folikel mengalami ovulasi dan memasuki fase luteal tertunda waktunya atau tidak terjadi sama sekali. Gejala yang nampak dari kasus ini adalah repeat bredeeer. Pada kasus anovulasi (kegagalan ovulasi), folikel de Graaf yang sudah matang gagal pecah karena ada gangguan sekresi hormon gonadotropin yaitu FSH dan LH (Jogjavet, 2008).

Dari hasil penelitian ini luas kandang dan sanitasi kandang berasosiasi negatif, hal ini berarti semakin luas kandang dan semakin bersih maka akan menurunkan tingkat kejadian RB. Kebutuhan luas kandang koloni yang ideal untuk seekor sapi adalah $4 \mathrm{~m}^{2}$ (Junaedi, 2011). Selain itu, luas kandang individu yang dibutuhkan untuk sapi potong adalah tak boleh kurang dari 2,0 $\mathrm{m}^{2} / \mathrm{ekor}$ atau volume kandang sebaiknya 5,0--6 $\mathrm{m}^{3}$ per ekor bila lingkungan kandang terkontrol (Santosa, 2004). Luas kandang yang semakin besar mengakibatkan ternak dapat lebih rileks, leluasa untuk bergerak, dan mempermudah peternak untuk melakukan sanitasi. Luas kandang yang kurang dari ukuran standar mengakibatkan sirkulasi udara terganggu dan sapi tidak bisa bergerak dengan bebas. Sirkulasi udara yang kurang baik secara terus menerus menyebabkan gangguan fisiologis kesehatan, sapi menjadi tercekam panas karena sapi merasa tidak nyaman dengan kondisi lingkungan yang dapat menyebabkan terjadinya penurunan produktifitas (Santosa, 2004).

Sanitasi kandang dilakukan untuk menjaga kesehatan ternak sapi melalui kebersihan. Oleh karena itu, frekuensi sanitasi kandang yang semakin sering dalam sehari semakin baik. Selain itu, untuk menjaga kesehatan, sapi juga perlu untuk dimandikan agar kotoran yang menempel pada tubuh hilang. Sanitasi terhadap kandang seharusnya dilakukan secara menyeluruh, yakni terhadap lingkungan sekitar dan terhadap peralatan yang berhubungan dengan ternak. Lingkungan yang kotor dan tidak terurus merupakan media yang baik bagi berbagai jenis serangga penyebar penyakit. Kutu dan caplak penghisap darah dapat bersarang dicelah-celah kandang sehingga sebaiknya merupakan sasaran utama dalam melakukan sanitasi.

Sugeng (2002), menyatakan bahwa kandang harus dibersihkan setiap hari dan sapi-sapi harus dimandikan setiap hari atau minimal satu minggu sekali. Pembersihan kandang dan dilanjutkan dengan pemandian sapi ini bertujuan untuk menjaga kebersihan kandang dan menjaga kesehatan sapi agar sapi tidak mudah terjangkit penyakit.

Umur pertama kali dikawinkan dari hasil penelitian ini berasosiasi positif, artinya semakin lama ternak dikawinkan maka akan meningkatkan RB. Perkawinan pertama pada sapi dara sebaiknya 
Suharyati, S dkk: Pengaruh Manajemen Peternak Terhadap Efesiensi Reproduksi Sapi Bali

dilakukan pada umur 14-16 bulan. Perkawinan yang terlambat melebihi umur 3 tahun cenderung menyebabkan penurunan prestasi reproduksi (Hardjopranjoto, 1995).

\section{KESIMPULAN}

Berdasarkan penelitian ini dapat disimpulkan bahwa efesiensi reproduksi sapi Bali di Kabupaten Pringsewu kurang baik berdasarkan nilai CR sebesar 51,75\%, S/C sebesar 1,76, CI sebesar 416,69 \pm 70,03 hari dan RB sebesar 18,18\%.

Faktor manajemen peternak yang berpengaruh terhadap efesiensi reproduksi adalah umur pertama kali dikawinkan menurunkan $\mathrm{CR}$ tetapi meningkatkan $\mathrm{CI}$ dan $\mathrm{RB}$, sanitasi kandang meningkatkan CR dan menurunkan RB dan SC, Luas kandang menurunkan SC dan RB. Pemberian hijauan dan kondisi tubuh meningkatkan CR, bentuk kandang dan kondisi tubuh menurunkan CR. Lantai kandang, umur penyapihan pedet dan nilai SC meningkatkan CI tetapi alas an beternak dan status reproduksi menurunkan CI. Tingkat pendidikan peternak menurunkan SC. Lama beternak dan sistem pemberian air menurunkan RB.

\section{DAFTAR PUSTAKA}

Bearden, H.J. dan J.W. Fuquay. 1984. Applied Animal Reproduction. Second edition. Reston Publishing Company. Inc. A prentice-Hall Company. Reston. Virginia

Hafez, E.S.E. 1997. Reproduction in Farm Animal, 7th Edition. Lea And Febiger. Philadelphia

Hardjopranjoto, H.S. 1995. Ilmu Kemajiran pada Ternak. Airlangga University Press. Surabaya

Hartono, M. 1999. Faktor-faktor dan Analisis Garis Edar Selang Beranak pada Sapi Perah di Kecamatan Musuk Kabupaten Boyolali. Tesis. Program Pasca Sarjana Universitas Gadjah Mada. Yogyakarta.

Irwan. 2011. Peran Air Bagi Hewan. http://irwansipetualang.blo gspot. com/ 2011/ 10/makalah-peranair-bagi-hewan.html Diakses 24 Januari 2015

Jogjavet. 2008. https://jogjavet.wordpress.com/2008/03/18/sapi-tidak-bunting-meski-sudah-diinseminasi-buatan-ib/ Diakses 24 Januari 2015.

Raffly. 2008. Kebutuhan Air Pada Ternak Non Ruminansia. Institut Pertanian Bogor. Bogor

Saka, I.K. 1990. Pemberian pakan dan pemeliharaan ternak kerja. Makalah dalam Pertemuan Aplikasi Paket Teknologi Sapi Potong. BIP Bali, Denpasar 10-13 Desember 1990

Santosa, U. 2004. Tatalaksana Pemeliharaan Ternak Sapi. Penebar Swadaya. Jakarta

Sarwono, J. 2006. Analisis Data Penelitian Menggunakan SPSS. Penerbit Andi.Yogyakarta.

Sudono, A. 2003. Produksi Sapi Perah. Departemen Ilmu Produksi Ternak. Fakultas Peternakan Institut Pertanian, Bogor.

Sugeng, Y.B. 2003. Sapi Potong. Penebar Swadaya. Jakarta.

Toelihere, M.R. 1993. Fisiologi Reproduksi Ternak. Angkasa. Bandung. 